\title{
The Rise of Non-State Actors in Globalization and Democratization Era: Terrorist Group versus State Actors
}

\author{
Aji Widiatmaja \\ Fajria Hasta Rizqi \\ ajiwidiatmaja@gmail.com \& fajriahasta@gmail.com
}

\begin{abstract}
Globalization brings together both mobility upheaval and democratization in technology for every state, organization, and people around the world. These phenomena make information, technology, and networking which a long time ago become state domain are today accessible for everyone. It gives a leeway for non-state actors which used to be powerless can speak louder in present day. However, this likely rejoice phenomena sometimes produce another side effect. The leeway also gives relatively easy access for certain non-state actors to achieve power that in the same time endanger world order. These non-state actors are terrorist groups which today possess great power, energized by globalization and democratization of technology, to balance the power of states. They utilize globalization and democratization era to organize, create image, build network, fund, and disseminate their activities around the globe. This study aims to analyze the rise of terrorist groups threats in today globalization and democratization era and in the same time examine the declining of state roles in international stages. This study uses descriptive qualitative method and using Globalization, Soft Power, and Balance of Power theories to dissect and analyze those phenomena. Several recommendations will be drawn from the analysis to contribute in making a robust and comprehensive international cooperation to combat terrorist groups.
\end{abstract}

Key words: globalization, state and non-state actors, terrorist group, soft power, balance of power 
Jurnal Sentris KSMPMI Vol. 2 - 2019

\section{Introduction}

In the end of the Cold War in the early 90's, nations which were separated in the socalled two blocks (west-east) started to integrate with one another. This phenomena could produce international cooperation or conflict among nations which is accelerated by the development of technologies. The integration and connection are borderless and could remove the territorial distance among international actors to constitute relations. This is called the era of globalization. International relations in today's globalized world has many faces, structures, and orders. Referring to what Hedley Bull said about international order, which is a pattern of activities to maintain primary and elementary goals of international societies ${ }^{1}$, the connections in globalization could be complicated since each state has its own agendas to be achieved. The complication is aggravated by the bifurcation of international relations actors, since it gave birth to new actors such as multinational corporations (MNCs), non-governmental organizations (NGOs), private security firms, social organization movement, transnational organized crime (TOC), and terrorist groups $^{2}$, which possess a quite powerful impact to balance the status quo. Those new actors are called non-state actors.

Globalization leads to democratization of things, meaning that the things used to be under state authority are now open to the public and freely accessed. For example, the possession of world mass destruction (WMD) or improvised explosive device (IED) by terrorist groups. Terrorist groups, which are the focus of this paper, use this advantages to strengthen its influence, operation, organization, funding, and communication. They have been building network to broaden its operation, and at the same time spread their ideology to rally their allies and followers across the globe. Prominent terrorist groups such as Al-Qaeda and Islamic State of Iraq and Syria (ISIS) operate globally by establishing connection with their allies in foreign countries. Their operations do not apply any formal law such as state political territorial and state sovereignty. In other words, their operations are literally borderless. AlQaeda affiliated with several terrorist groups in Middle East, African territories, and in South Asia. On the other hand, ISIS affiliated with its allies that spread in African territories, Middle East, South Asia, and Southeast Asia region.

The report from Center for Strategic and International Studies (CSIS) Transnational Threat Project in 2018 shows that the total group alliances consist of more than sixty Salafi-

\footnotetext{
${ }^{1}$ Hedley Bull, The Anarchical Society: A Study of Order in World Politics, $3^{\text {rd }}$ edition (New York: Palgrave, 2002), 8

2 Aituaje Irene Pogoson, "Non-state Actors, Terrorism and the New Global Reality", The Nigerian Journal of Sociology and Anthropology, Volume 16 No. 1, June (2018): 153.
}

ISSN 0216-5031

Copyright (C) 2018 Universitas Katolik Parahyangan 
Jurnal Sentris KSMPMI Vol. 2 - 2019

Jihadist groups in 2016 which estimated to have around 200,000 Salafi-Jihadist Fighters. The groups are spread across the globe, such as Europe, East Asia and the Pacific, Middle East, North Africa, Central Asia, South Asia, Sub-Saharan Africa. ${ }^{3}$ This fact shows that the existence of state actors (states) are under attack. Those terrormist groups insist to establish "Caliphate", a reign of Muslim ruler, to erase modern state system. Today's terrorist groups also possess ability in their operations by utilizing technology. They establish strong network and mobility across the globe. On the other hand, states still colliding with the application of globalization vis-à-vis sovereignty. State actors mobility are still limited by formal interactions and inflexibility in conducting relations or network. This phenomena gives advantages to terrorist groups since they can fully operate globalization and create their own borderless world. The power and authority of states in today's globalization and democratization era are declining. States need to build a robust strategy and cooperation to engage with the rise of non-state actors which in this case are terrorist groups. It is important to maintain the stability, security, and at the same time preserve sovereignty. However, utilization of those items in the real world by states are still problematic.

This paper will dissect the challenges in international security posted by globalization and democratization era. Moreover, it will specify the discussion about how terrorist groups (non-state actors) today can post great challenges for states security. This paper will also analyze the declining of state roles in globalization and democratization era. Several recommendations will be drawn from the analysis to give strategy alternatives in building a robust international cooperation to overcome the threat from terrorist groups. The analysis of the paper applies several theories such as soft power and balance of power to explain the rise of non-state actors (terrorist groups) that can be powerful challenges for states.

\section{Discussion}

\section{Globalization, Democratization, and the Rise of Non-State Actor (Terrorist Group)}

The key elements of globalization are integration and interconnection on a global level. Territorial distance seems to not be a major problem by the fact of high mobility of international actors in shaping international stage. Allison said that globalization phenomena leads to the expansion of certain network across the globe and at the same time connect individuals all around the world in specific dimension. He called it as "Identifiable Network". Then, global interconnection produces interdependency and reciprocity among individuals, groups, and

\footnotetext{
${ }^{3}$ CSIS Transnational Threat Project, The Evolution of the Salafi-Jihadist Threat: Current and Future Challenges from the Islamic State, Al-Qaeda, and Other Groups (Washington DC: CSIS, 2018), 7-10.

ISSN 0216-5031

Copyright (C) 2018 Universitas Katolik Parahyangan
} 
Jurnal Sentris KSMPMI Vol. 2 - 2019

states. ${ }^{4}$ Another definition related to globalization also stated by Pelegrinová and Lačný. They said that the principles of globalization are spontaneous and is an uncontrollable process which affect the global level and at the same time transform daily life of individuals. They added that globalization change societies and it is not reducible in certain territory, culture, and nation anymore. In fact, it is a phenomena that gradually decrease the borders of nation-states. ${ }^{5}$

Globalizations brings two different impacts, positive and negative. The positive impacts lies in the global interconnected and intensification of international cooperation in several aspects such as trade, culture, education, economy, politics, technology, defense, and security. However, as stated by Lee and Vivarelli, globalization has negative effects especially on the previously protected sectors. ${ }^{6}$ Today, some aspects that are used to be under state authority are now free to be accessed even by individuals. This seems good, but in certain aspects, it can produce critical challenges. For example, the challenge posted by the concept of "democratizing technology" proposed by Joseph Nye. He said that democratizing technology phenomena gives leeway to terrorist groups in accessing instrument of mass destruction ${ }^{7}$ and any other sophisticated technology which can balance state power.

This gives terrorist groups, as non-state actors, a power to shape world order. The globalization of insurgency, as stated by Vinci, is a phenomena that rise in the realm of globalization. It describes about armed groups as insurgents that hold power in international politics. They broaden its operations internationally in many aspects such as politics, economy, and military. Some of the groups are known as Lord's Resistance Army (LRA), Al Qaeda, National Union for the Total Independence of Angola (UNITA), and National Patriotic Front of Liberia (NPFL). ${ }^{8}$ Terrorist groups like Al-Qaeda, ISIS, and Abu Sayyaf spread Jihad ideology across the world to inspire their allied groups in doing terrorism. Moreover, the spread of Jihad ideology is energized by the development of communication technology that can deliver its message to individuals outside the groups. Then, the individuals can be influenced by the message of Jihad to do terrorism activities. This phenomena is called lone wolf terrorist, an individual act of terrorism which separate from central group or alliance. In fact, lone wolf terrorist is hard to detect since it is a random phenomena.

\footnotetext{
${ }^{4}$ Joseph Nye and John D. Donahue, Governance in a Globalizing World: Visions of Governance for the 21 st Century, (Massachusetts: Brookings Institution Press, 1999), 72-73.

${ }^{5}$ Lenka Pelegrinová and Martin Lačný, "The Impact of Globalization on Economies of Developed Countries", Journal of Economic Development, Environment and People, Volume 2, Issue 3 (2013): 25.

${ }^{6}$ Eddy Lee and Marco Vivarelli, "The Social Impact of Globalization in the Developing Countries", The Institute for the Study of Labor (IZA), Discussion Paper No. 1925 (2006): 2.

${ }^{7}$ Joseph Nye, Soft Power: The Means to Success in World Politics, (New York: Public Affairs, 2004), 22.

${ }^{8}$ Anthony Vinci, Armed Groups and the Balance of Power, (New York: Routledge, 2009), 1.
}

ISSN 0216-5031

Copyright @ 2018 Universitas Katolik Parahyangan 
Jurnal Sentris KSMPMI Vol. 2 - 2019

The spread of Jihad ideology leads to the making of what so-called imagined solidarity, a concept proposed by Asef Bayat. The main idea of imagined solidarity is the creation of common values and common interests that will lead to consensus and group solidarity. ${ }^{9}$ The solidarity creates unity among terrorist groups and make their organizations stronger and their operations broader. They, in fact, can do better in terms of making alliances and international cooperation in today's globalization and democratization era which at the same time state, as a state actor, still face several challenges in creating a robust international cooperation with other states. The difference between national interests and sovereignty issues is the uncommon views in international cooperation that become the major challenges for states. Globalization and democratization era give rise to non-state actors, which in this case are terrorist groups, and at the same time post critical challenges for states in shaping international order. The Morgenthau's balance of power is now happening.

\section{The Power of Terrorist Groups Today}

The Cold War phenomena gave contribution to the rise of terrorist groups in its proxy zone. The most prominent example is the birth of Al-Qaeda that rise from the ashes in the Middle East. The presence of United States troops in the region became the main cause of the rise of the modern jihad against the West. Roshandel states that the year 1979 marked the rise of the modern jihad called "Year Zero". The forms of their terrorism activities are interstate wars, separatism, insurgency, struggle for independence, and terrorism. Those terrorist groups, energized by jihad ideology, made the United States and Israel as the main targets since they spread secularism and imperialism in the Middle East. ${ }^{10}$

Among the groups, Al-Qaeda became the strongest as they posted the most dangerous attack. Data shows that in the early so-called "Year Zero", almost 500 US Citizens died in terrorist attacks by Hezbollah, Jihadis groups, and other terrorist groups. These facts are aggravated by the war declaration by Osama Bin Laden towards United States by bombing the US Embassies in Kenya and Tanzania in the year 1996 and 1998. ${ }^{11}$ The spread of jihad ideology through the internet and other sophisticated means of communication become great challenges for states. These phenomena give terrorist groups media to organize and broaden their

\footnotetext{
9 Asef Bayat, "Islamism and Social Movement Theory", New York: Routledge, Third World Quarterly, Vol. 26, No. 6, pp 891 - 908 (2005): 901.

${ }^{10}$ Jalil Roshandel and Sharon Chadha, Jihad and International Security, (New York: Palgrave MacMillan, 2006): 8-9.

11 James J.F. Forest, Countering Terrorism and Insurgency in the 21st Century: International Perspectives, (United States: Greenwood Publishing Group Inc., 2007): 3.
}

ISSN 0216-5031

Copyright (C) 2018 Universitas Katolik Parahyangan 
Jurnal Sentris KSMPMI Vol. 2 - 2019

cooperation and activities. Bierstaker and Eckert, in their book countering the Financing of Terrorism, mentions that Al-Qaeda had affiliated with approximately 40 groups across Asia, Africa, and Middle East known as Al-Qaeda Network. In fact, Al-Qaeda also funded, trained, and spread jihad ideology to terrorist groups in Pakistan, Sudan, Bosnia, Afghanistan, Chechnya, and Mindanao. ${ }^{12}$ Terrorist groups uses jihad ideology to energize and rally its allies across the world. They win "hearts and minds" from its audiences so they can influence them to do they are told to. This is reminding us about soft power.

Joseph Nye, a prominent figure that proposed the theory of soft power, stated that soft power is the ability to attain goals by using attraction rather than coercion. It arises from the attractiveness of culture, political ideals, and policies. ${ }^{13}$ He added that soft power is more than just an ability to persuade or to move people by arguments, but it is an ability to attract and it leads to acquiescence. ${ }^{14}$ By using the theory of soft power, the power of terrorist groups today can be explained. They expand its ideals and values across the globe to persuade, move, and finally acquiescence people to do terrorism. This kind of power, sometimes, does not owned by states. The absence of soft power by states, in certain point, can delegitimize state's authority and state can lose control over its people. Beside its soft power, terrorist groups also powered by the possession of sophisticated technology that can create improvised explosive device (IED). The Combination of soft and hard power owned by terrorist groups can balance the power of states that has lead the shaping of world order since long time ago.

The Morgenthau's balance of power can be utilized to dissect the effect of terrorist groups' power possession in today's globalization and democratization era. In his phenomenal work, Politics among Nations: The Struggle for Power and Peace, he stated that the aspirations for power which each try either to maintain, or to overthrow the status quo, will form a constellation called balance of power. ${ }^{15}$ Another argument about balance of power, also stated by Kaplan in Bull, is the existence of other powers whose abilities in influencing certain events are greater than zero. ${ }^{16}$ The possession of the soft and hard power of terrorist groups, as nonstate actors, present major challenges for states. Moreover, in today's globalization and

\footnotetext{
12 Thomas J. Bierstaker and Sue E, Countering the Financing of Terrorism, (New York: Routledge, 2008), 4849.

${ }^{13}$ Joseph Nye, Soft Power: The Means to Success in World Politics, X.

${ }^{14}$ Joseph Nye, Soft Power: The Means to Success in World Politics, 6

${ }^{15}$ Hans J. Morgenthau, Politics among Nations: The Struggle for Power and Peace, (New York: Alfred A. Knopf, 1948), 125.

${ }^{16}$ Hedley Bull. The Anarchical Society: A Study of Order in World Politics, 98.
} 
Jurnal Sentris KSMPMI Vol. 2 - 2019

democratization era states power seem to decline by seeing the bifurcation of world politics that give roles to actors other than states.

\section{The Declining Power of State Actors}

Terrorism phenomena can balance states power since it, as non-state actors, are more flexible in running its operations across the globe by combining hard and soft power. Terrorist groups utilize advanced technology to spread its influences in societies to persuade them and gain their sympathy. There are two methods that are used by terrorist groups on the internet to spread the influences. The methods are website and chat room. ${ }^{17}$ This is aggravated by the existence of social media that make communication among them easier and more effective in spreading messages. Before they conduct terrorism activities, they gather people by sending them radical contents in social media. The contents are meant to persuade and influence people to do terrorism. In terrorism activities in the name of Islam, the content being spread are clues to do jihad both joining terrorist groups abroad and in running individual act of terrorism in their homes. This kind of phenomena, at a certain point, is beyond state's extent since their communications are conducted in peer to peer and private messages.

Prominent terrorist groups such as ISIS and its allied group, Abu Sayyaf Group, in the Philippines utilize soft power through social media to gain power, mass, and at the same time defend their bases in Marawi, the Philippines. The government in those countries cannot defend its sovereignty since terrorist groups build their bases in their territories. In today's globalization and democratization era, the role and function of states are being challenged by the rise of non-state actors like terrorist groups. They, in fact, can establish their bases in a sovereign state. In 2018, a former ISIS member from Indonesia revealed that she knew ISIS from social media, specifically Facebook. She, then, went to ISIS base that was located in Syria and Iraq border to join them. After joining ISIS for several moments, she finally realized that what she had done was not right and considered ISIS as a criminal organization which spread fear. Then, she managed to flee and went back to Indonesia. In Indonesia, she joined deradicalization program under Badan Nasional Penanggulangan Terorisme (BNPT). ${ }^{18}$

Facebook is a social media platform that is used by most of Indonesians. Terrorist groups realize this and try to reach them by utilizing Facebook to spread their influences. At the same time, terrorist groups penetration in Facebook has higher intensity and influence rather than states. This phenomenon has caused states and governments lose control of its

\footnotetext{
${ }^{17}$ Marc Sageman, Leaderless Jihad, (Pennsylvania, University of Pennsylvania Press, 2008), 113.

${ }^{18}$ Sri Lestari. "Gadis yang bujuk keluarganya hijrah ke Suriah: 'ISIS telah membajak dan merusak Islam"”. BBC.com. https://www.bbc.com/indonesia/indonesia-43848676 (accessed May 12, 2019)

ISSN 0216-5031

Copyright (C) 2018 Universitas Katolik Parahyangan
} 
Jurnal Sentris KSMPMI Vol. 2 - 2019

society and at the same time lose its influence, role, and function. Today's globalization and democratization era post great challenges to states and government.

Post terrorist acts often followed by its information spread on social media that show pictures or video of terrorist acts in a certain country or region. This will create fear and insecurity for people and delegitimize states role since they cannot provide security for its people. The right to feel free from fear, right to live, liberty, and security ${ }^{19}$ are now being threatened by terrorism and states seem face difficulties to overcome it. The fear in societies will affect people's productivity, damage infrastructure, and give negative impact in economy especially in investment. According to Rasheed and Tahir, foreign direct investment (FDI) in certain country will decrease when terrorism activity rises and vice versa. ${ }^{20}$ Terrorism activities in certain country will create distrust for people as well as investor that will move their investment in a safer place.

On the other hand, to establish international cooperation to combat terrorism, states are still facing difficulties because the existence of sovereignty. Southeast Asia region is an example of region that experience long history of terrorism. However, it is also quite difficult for the region to build a robust regional cooperation, because it still straightly maintain its sovereignty. In fact, to combat terrorism that do not utilize political territory for its operations, similar kind of transnational cooperation among states also greatly needed. Indonesia, Malaysia, and the Philippines have gone through a long journey to establish joint patrol policy in Sulu Sea to combat piracy. One of the piracy acts in the region was run by Abu Sayyaf Group towards Indonesian flagged ship in 2016. ${ }^{21}$ However, the cooperation has some challenges. In the early establishment, the cooperation still lacks clear agreement due to the difference in perceiving threats and determining patrol territories. When conducting joint patrol, each ship from each country should sail side by side to prevent territorial violation by other ships while pursuing targets. The other problem is related to join exercise or joint training, which sometimes does not address the problems due to the different form of terror of each state. Moreover, the difference in geographical landscape will also effect strategies in combating

19 UNHCR. "Universal Declaration of Human Rights" Article 02 and Article 03. UN.org. https://www.un.org/en/udhrbook/pdf/udhr_booklet_en_web.pdf (accessed May 12, 2019)

${ }^{20}$ Hafsa Raseed and Muhammad Tahir, "FDI and Terrorism: Co-intergration \& Granger Causality", International Affairs and Global Strategy, Journal ISSN 2224-8951 Vol.4 (2012): 5.

21 Azizah Fitriyanti. "Indonesia-Filipina-Malaysia Lakukan Pengamanan Berlapis di Laut Sulu". ANTARANEWS.com. https://www.antaranews.com/berita/601409/indonesia-filipina-malaysia-lakukanpengamanan-berlapis-di-laut-sulu (accessed May 13, 2019) 
Jurnal Sentris KSMPMI Vol. 2 - 2019

terrorism. Joint training and joint exercises are valued as ineffective to address the current problems.

The utilization of social media by terrorist groups post a great challenge for states since they can spread its influences and their terrorism activities fast. Moreover, terrorist groups can gain sympathy from people, and at the same time produce enormous fear among societies. In this case, we can say that states lose its power when dealing with such phenomena. International cooperation always involves each states national interest with it, and sometimes be an obstacle in establishing cooperation. Seeing these phenomena, states need to build a robust international cooperation that can deal with terrorism threat.

\section{Strategies in Combating Terrorist Groups}

Through Global War on Terror (GWOT) policy by United States after 9/11, the development of counter-terrorism regime began. United States uses democracy as a tool to quell terrorism from Moslem community. ${ }^{22}$ First, Afghanistan was invaded because of its association with the Taliban, then continued to invade Iraq. Middle East became the target of democratization due to its affiliation with terrorist groups. Many authoritarian regimes in Middle East had been accused of being the root cause of terrorism since poverty on its society had provoked the rise of terrorism. The US was also worried by the fact that Middle East might support terrorists by supplying the weapon of mass destruction. ${ }^{23}$ Terrorism started to rise and lodged in Indonesia, Malaysia and the Philippines. On the other hand, SAVE (Struggle Against Violence Extremism) policy has been provided by The United States to combat terrorism in Southeast Asia region. ${ }^{24}$ Both policy did not effectively address the root cause of terrorism, on the contrary the policies could create more targets for terrorist and weaken the response of states, also might produce fewer allies in combating terrorism. ${ }^{25}$ States should implement soft power to complement the use of hard power as a counter-terrorism strategy. By using soft power alongside hard power, it will strengthen the existing cooperations and reduce ineffectiveness of countering terrorism cooperation.

New Zealand and Sri Lanka have made progress in using soft power after terrorist attacks in 2019. A mosque in New Zealand was brutally attacked by a terrorist and killed

\footnotetext{
${ }^{22}$ Forest, Countering Terrorism, 60-61.

${ }^{23}$ Ibid., 60.

${ }^{24}$ Anne Aldis and Graeme P. Herd, The Ideological War on Terror: Worldwide Strategies for Counter-Terroris, (New York, Routledge, 2007), 128

${ }^{25}$ Forest, Countering Terrorism, 64
} 
Jurnal Sentris KSMPMI Vol. 2 - 2019

dozens of people in March 2019. New Zealand asked some social media company to delete all posts about the terrorist attack which brought the society into restlessness and also monitoring social media network in New Zealand. ${ }^{26}$ The government took an initiative to freeze some social media such as Facebook and Instagram to reduce public fear, since there had also been a terrorist attack in some churches and hotels in Sri Lanka. ${ }^{27}$ Based on the two case studies above, globalization brings a new pattern in counter-terrorism. State should monitor social media where every individuals could access any information including terrorism contents. It is important to reduce the effects of terrorism and prevent the next terror from happening. As International Centre for Study of Violent Extremism (ICVSE) stated, terrorist groups nowadays use soft power as their propaganda. ${ }^{28}$ They use social media such as Facebook, Youtube, and chat provider like Whatsapp, even with online electronic sport activity which contain violence. The existence of social media itself is one of the key elements of the rise of non-state actors. Social media could drive mass and people only with one viral content which published by peer to peer network and because it is accessible to the whole society.

State should be able to balance the power of non-state actors today to gain trust from its society, especially on security scope. Emphasizing cooperation with social media and chat provider as multinational company is one rational option which should be considered by state to elevate counter terrorism cooperation. The cooperation must include sharing information about digital track record of terrorist suspect, digital track record of disseminator of the viral violence content, and use social media as a platform to spread campaign against terrorism. An advertisement on social media could even brought back members of Fuerzas Armadas Revolucionarias de Colombia (FARC), a terrorist group, to their home in Colombia, in 2013. ${ }^{29}$ Not only to counter-terrorism, cooperation with social media will also prevent many kind of violence so that it won't spread in the society.

Beside the usage of social media as state's soft power to counter-terrorism, international cooperation should be developed by state to balance the role of terrorism. Cooperation using soft power did not eliminate the hard power which has existed before, instead it works as

\footnotetext{
${ }^{26}$ Charlotte Graham-McLay. "NZ Mosque Attacks Suspect Tarrant to Face 50 Murder charges". Aljazeera.com. https://www.aljazeera.com/news/2019/04/zealand-mosque-attacker-tarrant-face-50-murder-counts190404042725489.html (accessed May 13, 2019)

${ }^{27}$ Sugam Pokharel, Euan McKirdy and Tara John. "Bombs tear through Sri Lankan Churces and Hotels, Killing 250 People". CNN.com. https://edition.cnn.com/2019/04/21/asia/sri-lanka-explosions/index.html (accessed May 12, 2019)

${ }^{28}$ ICSVE: Soft Power Approaches to Countering Terrorism Panel at the National Press Club, (10 April 2018)

29 Brit Mccandless.," Advertising to sell peace not products". CBSNews.com. https://www.cbsnews.com/news/60-minutes-colombia-advertising-to-sell-peace-not-products/ (accessed May 12, 2019)
} 
Jurnal Sentris KSMPMI Vol. 2 - 2019

complementary. State should build cooperation to synchronize the perspectives of threat. Dialogue and discussion forums must be attended by stakeholder among countries to gain mutual trust. For example, in Southeast Asia region, ASEAN has a forum named ASEAN Defense Ministers' Meeting Plus (ADMM-Plus) attended by ASEAN members and ASEAN country partners which promotes dialogues and discussions to share information in enhancing the capacity building, gaining mutual trust, Confidence Building Measure (CBM), and also to improve security sector and regional stability against transnational organized crime. ${ }^{30}$ This is a good step in harmonizing perceptions of threats among countries in region and also help states to create mutual trust in establishing a robust international cooperation to combat terrorism. ADMM Plus is just an example, the point is that forum for discussion between states' stakeholders is needed to enable a comprehensive cooperation. It will be better if in every discussion forum, states also invite other parties such as academicians, professionals, and thinkthank from all around the world to share information and play an active role in the discussion. The involvement of other non-state actors in the discussion will enhance states' soft power since it will be an inclusive international cooperation.

\section{Conclusion}

The rise of non-state actor in globalization and democratization era has two inverse sides which are positive and negative. The positive side is that the presence of non-state actor could help develop various sectors among states and individuals. However, the negative side is that non-state actor could decline the role of state and become a threat to the society, where the existence of terrorist groups is an example. The presence of terrorist group has many bad impacts to state, as the highest organization which functions as the protection of its citizens. Terrorism makes state's role decline because terror causes panic and fear among people, lowering the foreign direct investment, and able to violate state sovereignty by set up bases in its territory. They operate in a borderless world which make its movement very flexible. To overcome such phenomena, states must adapt and adopt cooperation that facilitates flexibility and effectivity in combating terrorism by managing sovereignty issues.

The evolving terrorism activity has combined soft and hard power in carrying out its actions. In order to balance and suppress terrorist groups power, state must also combine soft power and hard power approaches. The strategy is divided into no-terror and post-terror, where both have the same approaches which is comprehensive cooperation with social media as a

30 ADMM. "About the ASEAN Defence Ministers' Meeting (ADMM-Plus)". ASEAN.org. https://admm.asean.org/index.php/about-admm/about-admm-plus.html (accessed May 13, 2019)

ISSN 0216-5031

Copyright @ 2018 Universitas Katolik Parahyangan 
Jurnal Sentris KSMPMI Vol. 2 - 2019

state soft power. In times of no-terror situation, government should be able to monitor the viral contents which could lead society to do violence both in international and national scope. Meanwhile, in post-terror time, the government must be able to track the digital record of terrorists suspect and track the networks. Furthermore, the government should ban the content of violations related to the terror in order not to spread fearness in society. Moreover, soft power must also be used to build international cooperation to improve mutual trust and Confidence Building Measures (CBM) through intense dialogue and discussion forums to synchronize the perception of threats so that comprehensive cooperation will be easily implemented. It is important to complement joint patrol or joint exercise cooperation which sometime has rigid mechanism and inflexible. The presence of other non-state actors such as academicians, professionals, and think-thank in stakeholder discussions can enhance states' soft power. 
Jurnal Sentris KSMPMI Vol. 2 - 2019

\section{References:}

Aldis, Anne \& Herd, Graeme P. The Ideological War on Terror: Worldwide Strategies for Counter-Terroris. New York: Routledge, 2007.

Bayat, Asef. "Islamism and Social Movement Theory". New York: Routledge, Third World Quarterly, Vol. 26, No. 6, pp 891 - 908 (2005): 901.

Bierstaker, Thomas. J and Eckert, Sue. Countering the Financing of Terrorism. New York: Routledge, 2008.

Bull, Hedley. The Anarchical Society: A Study of Order in World Politics. 3rd edition. New York: Palgrave, 2002.

Center for Strategic and International Studies (CSIS). CSIS Transnational Threat Project. The Evolution of the Salafi-Jihadist Threat: Current and Future Challenges from the Islamic State, Al-Qaeda, and Other Groups, by Seth G. John, Charles Valle, Danika Newlee, Nocholas Harington, Clayton Sharb, Hannah Byrne. Washington DC. 2018.

Forest, J. F. James. Countering Terrorism and Insurgency in the 21st Century: International Perspectives. United States: Greenwood Publishing Group Inc., 2007.

Lee, Eddy \& Vivarelli, Marco. "The Social Impact of Globalization in the Developing Countries". The Institute for the Study of Labor (IZA), Discussion Paper No. 1925 (2006): 2

Morgenthau, Hans J. Politics among Nations: The Struggle for Power and Peace. New York: Alfred A. Knopf. 1948

Nye, Joseph. Soft Power: The Means to Success in World Politics. New York: Public Affairs, 2004

Nye, Joseph, \& Donahue, John. D. Governance in a Globalizing World: Visions of Governance for the 21st Century. Massachusetts: Brookings Institution Press, 1999.

Pelegrinová, Lenka \& Lačný, Martin. "The Impact of Globalization on Economies of Developed Countries". Journal of Economic Development, Environment and People, Volume 2, Issue 3 (2013): 25

Pogoson, Irene Aituaje. "Non-state Actors, Terrorism and the New Global Reality". The Nigerian Journal of Sociology and Anthropology, Volume 16 No. 1, June (2018). 153

Raseed, Hafsa \& Tahir, Muhammad. "FDI and Terrorism: Co-intergration \& Granger Causality". International Affairs and Global Strategy, Journal ISSN 2224-8951 Vol.4 (2012): 5

Roshandel, Jalil and Chadha, Sharon. Jihad and International Security. New York: Palgrave MacMillan, 2006.

Sageman, Marc. Leaderless Jihad. Pennsylvania: University of Pennsylvania Press, 2008.

Vinci, Anthony. Armed Groups and the Balance of Power. New York: Routledge, 2009.

\section{Internet Source:}


Jurnal Sentris KSMPMI Vol. 2 - 2019

ADMM. "About the ASEAN Defence Ministers' Meeting (ADMM-Plus)". ASEAN.org. https://admm.asean.org/index.php/about-admm/about-admm-plus.html (accessed May $13,2019)$

Fitriyanti, Azizah. "Indonesia-Filipina-Malaysia Lakukan Pengamanan Berlapis di Laut Sulu”. ANTARANEWS.com. https://www.antaranews.com/berita/601409/indonesia-filipinamalaysia-lakukan-pengamanan-berlapis-di-laut-sulu (accessed May 13, 2019)

Graham-McLay, Charlotte. "NZ Mosque Attacks Suspect Tarrant to Face 50 Murder charges". Aljazeera.com. https://www.aljazeera.com/news/2019/04/zealand-mosque-attackertarrant-face-50-murder-counts-190404042725489.html (accessed May 13, 2019)

ICSVE: Soft Power Approaches to Countering Terrorism Panel at the National Press Club, (April 10, 2018)

Lestari, Sri. "Gadis yang bujuk keluarganya hijrah ke Suriah: 'ISIS telah membajak dan merusak Islam””. BBC.com. https://www.bbc.com/indonesia/indonesia-43848676 (accessed May 12, 2019)

Mccandless, Brit. " Advertising to sell peace not products". CBSNews.com. https://www.cbsnews.com/news/60-minutes-colombia-advertising-to-sell-peace-notproducts/ (accessed May 12, 2019)

Pokharel, Sugam, McKirdy, Euan \& John, Tara. "Bombs tear through Sri Lankan Churces And Hotels, Killing 250 People”. CNN.com. https://edition.cnn.com/2019/04/21/asia/srilanka-explosions/index.html (accessed May 12, 2019)

UNHCR. "Universal Declaration of Human Rights" Article 02 and Article 03. UN.org. https://www.un.org/en/udhrbook/pdf/udhr_booklet_en_web.pdf (accessed May 12, 2019) 
Jurnal Sentris KSMPMI Vol. 2 - 2019

\begin{tabular}{|c|}
\hline $\begin{array}{l}\text { ABOUT THE AUTHOR } \\
\text { Aji Widiatmaja is a researcher in } \\
\text { Center of Defense Diplomacy Studies, } \\
\text { Indonesia Defense University. He } \\
\text { focuses his research on Southeast } \\
\text { Asian Studies, Defense Diplomacy, } \\
\text { and Terrorism Studies. } \\
\text { Aji obtains scholarship from } \\
\text { Indonesia Defense University and } \\
\text { attains his master's degree in Defense } \\
\text { Diplomacy. } \\
\text { Aji Widiatmaja } \\
\text { Phone: +62 81391190539 } \\
\text { ajiwidiatmaja@gmail.com }\end{array}$ \\
\hline
\end{tabular}

\begin{tabular}{|c|l|} 
ABOUT THE AUTHOR \\
$\begin{array}{l}\text { Fajria Hasta R. is a post graduate } \\
\text { students of Peace and Conflict } \\
\text { Resolution Program at Indonesia } \\
\text { Defense University. }\end{array}$ \\
$\begin{array}{l}\text { Fajria Hasta Rizqi } \\
\text { Phone: +62 87773336167 } \\
\text { fajriahasta@gmail.com }\end{array}$ \\
\hline
\end{tabular}


